\title{
Preliminary Design and Development of a Coupled Water Resources Resiliency Model of the St. Johns River Watershed Florida, USA +
}

\author{
Christopher Brown 1,*, Samantha Kovalenko ${ }^{1}$, Cigdem Akan ${ }^{2}$, Barsha Tripathee ${ }^{2}$ \\ and Don Resio ${ }^{2}$ \\ 1 School of Engineering, University of North Florida, Jacksonville, FL 32224, USA; n00945365@unf.edu \\ 2 Taylor Engineering Research Institute, University of North Florida, Jacksonville, FL 32224, USA; \\ cigdem.akan@unf.edu (C.A.); n01448395@unf.edu (B.T.); don.resio@unf.edu (D.R.) \\ * Correspondence: christopher.j.brown@unf.edu; Tel.: +1-904-620-2811 \\ † Presented at the 4th International Electronic Conference on Water Sciences, 13-29 November 2019; \\ Available online: https://ecws-4.sciforum.net/.
}

Published: 12 November 2019

\begin{abstract}
The St. Johns River watershed, located in Florida, USA, is the focus of planning efforts to improve the resiliency and management of water resources infrastructure from current and future flood threats. These threats are driven by intense urbanization of the basin combined with increased frequency and intensity of coastal storms, made worse by sea level rise. Research efforts have begun to develop a comprehensive system of coupled numerical simulation models of the entire watershed in order to assess the current and long-term risks from flood inundation. This study provides a discussion of the system-wide model design and preliminary development. The study first outlines the project area and various numerical models to be coupled together. Then, the study discusses preliminary model development efforts and challenges. This initial study revealed the overall complexity and size of the undertaking. Overall, the study's primary conclusion is that while an integrated system of coupled models is feasible and potentially very useful for long-term planning, the computational challenges for such an undertaking are extensive.
\end{abstract}

Keywords: St. Johns River; model; surface water; system model; flood simulation

\section{Introduction}

This article explores preliminary design and development of a large coupled water resources model of the St. Johns River basin in Florida, USA. The actual model under development is a system of models coupled together at natural boundaries. The models include an oceanic model coupled to an inland hydrodynamic model, coupled to multiple sub-basin hydraulic and hydrologic models. The system of models is being developed to assess flood risks in the watershed due to a combination of rainfall-driven flooding, sea level rise at the river outlet, and urbanization occurring within the watershed. The "resiliency" of the watershed to resisting flooding is of particular interest. The new model builds upon past simulation efforts in the study area and expands them so that a realistic evaluation of the resiliency of the people and infrastructure within the watershed can be assessed from the base year 2020 through the 50-year study period, ending in 2070.

The St. Johns River watershed is quite vast and covers a large area of central and northeast Florida, USA. The watershed is approximately $22,380 \mathrm{~km}^{2}$ and is about $483 \mathrm{~km}$ long, with a slope of $0.0158 \mathrm{~m} / \mathrm{km}$ resulting in a wide river with meanders, wetlands, and lack of a defined channel in some areas [1]. Figure 1 depicts the entire study area, including the many sub-basins of importance. The 
remaining sections of this article provide a short overview of the collection of models under consideration for coupling as well as the challenges to be overcome due to the system size and complexity.

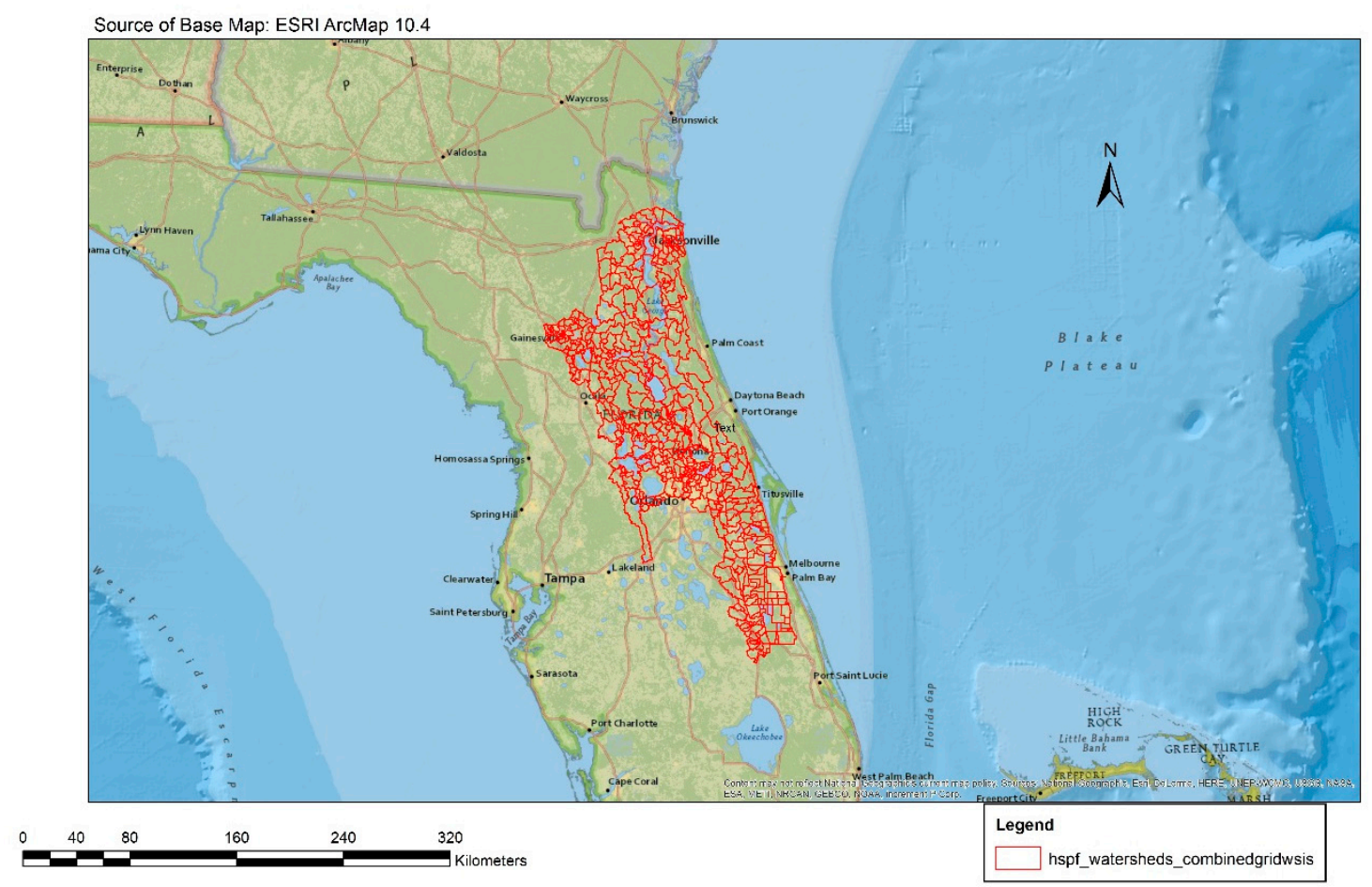

Figure 1. Project study area covering the St. Johns River watershed in Florida, USA.

\section{Materials and Methods}

\subsection{COAWST Modeling System}

In order to capture the potential effects of ocean tide as well as possible storm surge, the research team proposes to use the Coupled Ocean-Atmosphere-Wave-Sediment Transport modeling system (COAWST) which was developed by Warner et al. [2]. This three-way coupled system consists of following modules: an atmospheric model (Weather Research and Forecasting; WRF), a threedimensional hydrostatic ocean model (Regional Ocean Modeling System; ROMS) and a wave generation and propagation model (Simulating Waves Nearshore; SWAN). The COAWST modeling system also has the capability of coupling to an ecosystem and nitrogen-based biogeochemical model for future simulation of water quality changes in the St. Johns River system. The ROMS model will also be extended inland to cover the tidal portions of the St. Johns River. This portion of the model will be called the "hydrodynamic" model. ROMS solves hydrostatic equations for an incompressible fluid with a free surface. It uses generalized terrain-following coordinates, the Boussinesq approximation using a realistic Equation of State (EOS) for seawater, and general orthogonal curvilinear coordinates in horizontal directions. The model domain selection is an important consideration for the study. It must take into account a number of conditions including:

- $\quad$ The current estimated extent of the flood plain based upon Flood Insurance Studies [3];

- Sea level rise between 2020 and 2070;

- Tidal influence upstream from the river mouth;

- Planned water resources projects in the watershed; and,

- Future urbanization of the watershed that may increase flood flows.

Figure 2 depicts a conservative model domain currently under consideration for the inland hydrodynamic part of the model system. 


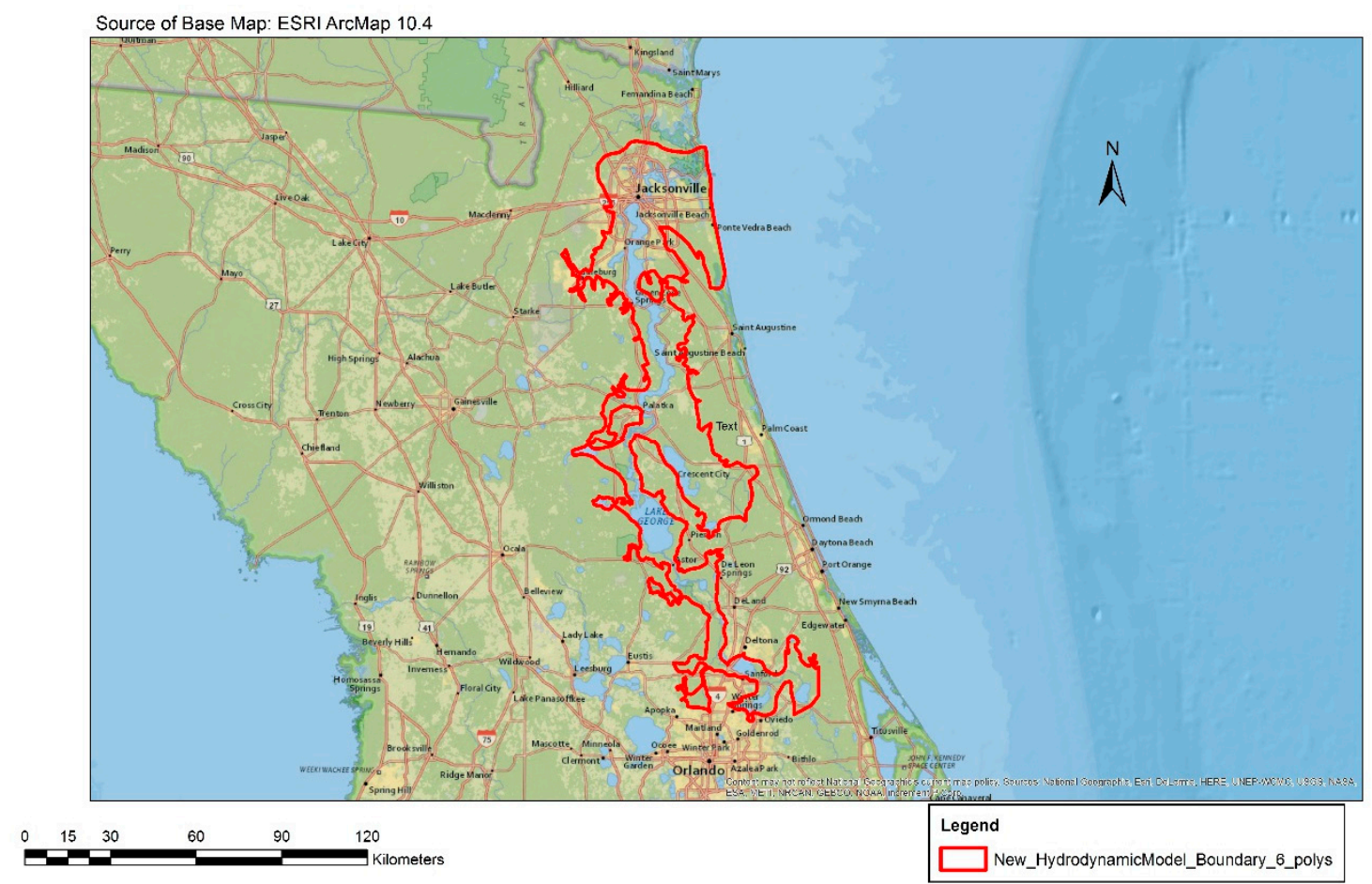

Figure 2. Project study area showing possible extent of inland model domain.

\subsection{Hydraulic and Hydrologic Models}

The COAWST modeling system is coupled to multiple hydrologic models that simulate the various sub-basins within the watershed. The St. Johns River Water Management District has recently developed and compiled HSPF hydrologic models for many sub-basins in the study area [4]. The models cover a majority of the sub-basins of interest for the new model domain. Tancreto developed a large HEC-HMS hydrologic model of the upper St. Johns River basin and portions of the middle St. Johns River basin [5]. This model may be used in place of some of the existing HSPF models available or as a basis for comparison for the HSPF models that cover the same area. In addition, an adaptive hydraulic model (ADH) has been developed for the middle St. Johns River basin that extends from the southern inlet of Lake Harvey downstream (e.g., north) to Deland, Florida. The ADH or the "adaptive hydraulics" model is a finite-element model that simulates two-dimensional overland flow and two-dimensional depth-averaged surface water flow [6]. The ADH model could be used to reduce the computational domain of the ROMS hydrodynamic model by passing flows from the upper St. Johns River and middle St. Johns River basins to the main stem of the St. Johns River at Deland, Florida. The location of the ADH northern boundary correlates with the actual location of a stream gauge that measures flow and discharge on the river. Therefore, this location could serve as an ideal alternate southern boundary to the ROMS model instead of extending it upstream to Lake Harvey.

\section{Results}

\subsection{COAWST Modeling System}

Three-level nested-grid realistic configurations of the East Florida Coast were conducted. The coarsest horizontal resolutions of level-1, level-2, and level-3 models were approximately, $1 \mathrm{~km}, 250$ $\mathrm{m}$ and $75 \mathrm{~m}$, respectively. The resolution was increased in the important portions' domain (such as upper and lower St. Johns River) at each level. All levels include tides, and level-2 and level-3 simulations also include the wave effects and biogeochemistry. 
The respective grid sizes starting from level-1 through level-3 were, $(1410 \times 770 \times 50),(1600 \times 80$ $\times 50)$, and $(1600 \times 800 \times 40)$. It is estimated that the level- 1 simulations would take approximately two weeks and the other two levels would take $2-3$ months using 256 processors.

\subsection{Hydraulic and Hydrologic Models}

Initial evaluation and testing of the HSPF, HEC-HMS, and ADH models indicated that the most efficient system of models would be to utilize the HEC-HMS model as an input to Lake Harvey for the upper St. Johns River basin and then utilize the existing HSPF models for the middle St. Johns and lower St. Johns River basins. The use of the ADH model would be optional as it is only useful as a means to reduce the computational overhead of the ROMS hydrodynamic model. The ADH model covered a model domain of about $150 \mathrm{~km}^{2}$, or about $62 \mathrm{~km}$ of the St. Johns River system. The ADH model contained approximately 51,000 mesh nodes with the smallest element having a length of 40 $\mathrm{m}$. In the initial computational tests, the ADH model took about $18 \mathrm{~h}$ to simulate 32 days using an Intel series core i9-9900 chipset using ten logical processors. Using the ADH model would probably reduce the model domain of the ROMS hydrodynamic model by $10 \%-15 \%$. The ADH model domain is shown in Figure 3.

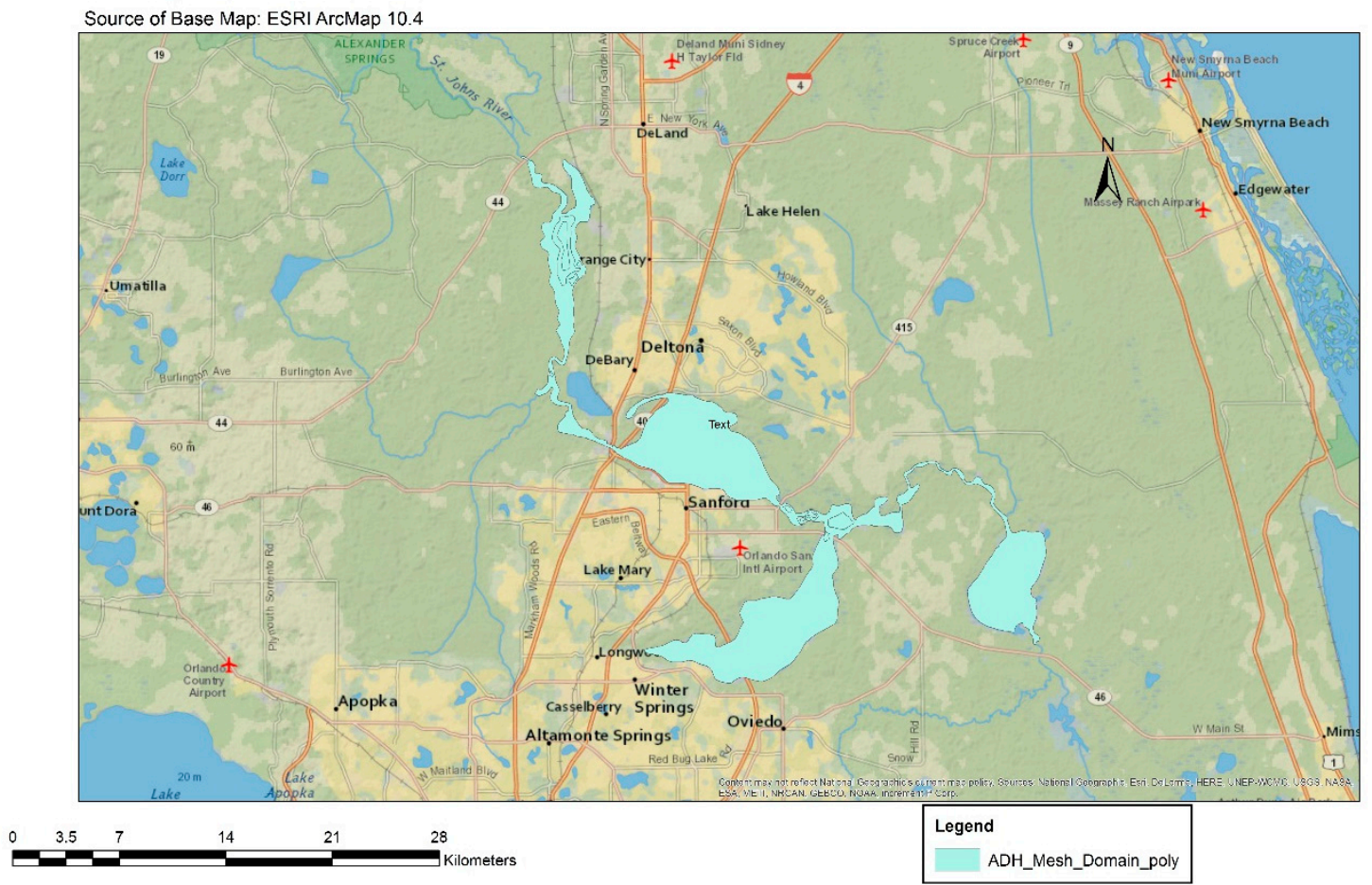

Figure 3. Project study area showing the extent of ADH model domain.

\section{Discussion}

Overall, this study has provided the beginnings of a focused research effort, with the goal being the development of a system of models to simulate the entire St. Johns River basin for the purposes of flood resiliency. The preliminary model development results clearly show the difficulties in simulating the entire watershed. First, when combining the effects of a $1 \%$ flood with a high stage with sea level rise and urbanization, the model domain size quickly becomes giant when compared to simply simulating the river at normal pool. In fact, the model domain more than doubles. Second, in order to capture the system complexity, two-dimensional or three-dimensional model codes are desired, yet these lend themselves to long computer run times. For example, to simulate 32 days of actual time, the ADH model takes about $18 \mathrm{~h}$ on a workstation using ten logical processors. For the system of model under discussion, it is likely than at least one year of time may have to be simulated. Using the same workstation computer, the ADH model would run for $205 \mathrm{~h}$ (e.g., 8.54 days) to 
simulate one year of actual time. This basically means that the ROMS model, which will have a model domain seven to eight times larger, may take up to 65 days to run one year on the same workstation. Therefore, the ROMS model will need to be deployed to a super computing cluster in order for the model run times to be useful for the research team. Lastly, a separate challenge facing the team is to decide what combination of fresh-water floods to use for each sub-basin attached to the hydrodynamic ROMS model. For a typical large-scale precipitation event, not all sub-basins contribute to the river flood flows and the remaining basins may be subject to different return frequency events. Therefore, the research team needs to develop a methodology to "distribute" a large-scale precipitation event appropriately across the large model domain.

\section{Conclusions}

In summary, this initial effort provided an overview of the system of models under development in order to simulate flood resiliency in the St. Johns River basin. Future tasks to be performed include the final development, calibration, and validation of the ROMS hydrodynamic model, as well as additional integration of the sub-basin hydrologic models. Further studies are also necessary to devise an appropriate methodology to distribute precipitation events across the large simulated study area. Finally, the large computational demands of the system of models generally means that the use of a super computing cluster of computers is mandatory.

Author Contributions: C.B., C.A. and D.R. led the research efforts for this article as part of an ongoing research program. The development of the ADH model and integration of the sub-basin hydrologic models is being overseen by C.B. The ROMS model development is being overseen C.A. and D.R., S.K., and B.T. are assisting with model development and integration. This article was written by C.B. and C.A., with review by D.R., and C.B. provided project administration and final article editing. All authors have read and agreed to the published version of the manuscript.

Funding: This research was unfunded and completed by research team as part of a large grant proposal effort.

Acknowledgments: The authors would like to acknowledge the help and support of the Johns River Water Management District, who provided historical model datasets and map coverages used for this study.

Conflicts of Interest: The authors declare no conflict of interest. No one other than the authors had a role in the design of the study; in the collection, analyses, or interpretation of data; in the writing of the manuscript, or in the decision to publish the results.

\section{References}

1. St. Johns River Water Management District. Chapter 2, Comprehensive Integrated Assessment, St. Johns River Water Supply Impact Study, Technical Publication SJ2012-1; St. Johns River Water Management District: Palatka, FL, USA, 2012; 108p.

2. Warner, J.C.; Armstrong, B.; He, R.; Zambon, J. Development of a coupled ocean-atmosphere-wavesediment transport (COAWST) modeling system. Ocean Model. 2010, 35, 230-244.

3. United States Federal Emergency Management Agency. Flood Insurance Study Duval County, Florida (All Jurisdictions); Federal Emergency Management Agency: Washington, DC, USA, 2018.

4. St. Johns River Water Management District. Chapter 3, Watershed Hydrology, St. Johns River Water Supply Impact Study, Technical Publication SJ2012-1; St. Johns River Water Management District: Palatka, FL, USA, 2012; 223p.

5. Tancreto, A.E. Comparison of Hydrologic Model Performance Statistics Using Thiessen Polygon Rain Gauge and NEXRAD Precipitation Input Methods at Different Water-Shed Spatial Scales and Rainfall Return Frequencies. Master's Thesis, University of North Florida, Jacksonville, FL, USA, 2015. Paper 584. Available online: http://digitalcommons.unf.edu/etd/584 (accessed on 15 October 2018).

6. U.S. Army Corps of Engineers ERDC. Adaptive Hydraulics 2D Shallow Water (ADH-SW2D) User Manual (Version 4.6); U.S. Army Corps of Engineers Engineer Research and Development Center: Vicksburg, MS, USA, 2017; 133p. 
(C) 2019 by the authors. Licensee MDPI, Basel, Switzerland. This article is an open access article distributed under the terms and conditions of the Creative Commons Attribution (CC BY) license (http://creativecommons.org/licenses/by/4.0/). 